山崎 俊一*・鈴木 忠*・藤川 達夫*

\title{
ANALYSIS OF INFLUENCE OF DRUM CURVATURE ON TIRE TREAD WEAR IN INDOOR WEAR TEST
}

\author{
Shunichi YAMAZAKI, Tadashi SUZUKI, Tatsuo FUJIKAWA (Japan Automobile \\ Research Institute, Research Division 2, 2530, Karima, Tsukuba, Ibaraki 305, \\ Japan)
}

Indoor test machines have been used for evaluating tire tread wear because of actual vehicle testing required much cost and time. The research paper was published and was described that the tread wear due to the drum was the same tread wear with the flat belt. Vehicles mainly travel on flat road surfaces. Therefore, a flat belt type machine should be used for investigating tire tread wear. Drum type machines, however, are used as economical testing machines.

In this paper, we investigated analytically the influence of drum curvature on the tire tread wear by calculating the friction energy in the contact surface. The analytical results were compared with experimental results that had published. We obtained the relationship between the friction energy on the flat belt and on the drum. Analytical results was good agreement with experimental results.

(Received on April 28, 1997)

Key word: Tire, Tread Wear, Flat Belt, Drum, Friction Energy, Actual Vehicle Test, Indoor Test

\section{1. ま え がき}

実車試験によるタイヤの摩耗評価は，多くの時 間と経費がかかるために，その代用として室内夕 イヤ試験機が用いられている11. 室内夕イヤ試験機 には，ドラム式とフラットベルト式があり，両者 は路面曲率が異なるために接地状況が異なり, 試 験結果の差異は大きいと考えられる。最近，ドラ ム試験機によるトレッド摩耗量がフラットベルト 試験機による摩耗量とほぼ同一であるという研究
結果が報告された2). 車両は, 比較的平らな路面を 走行しているので, 室内夕イヤ摩耗試験には, フ ラットベルト式の試験機を用いることが望ましい が，ドラム式夕イヤ試験機が多く用いられている.

本研究では, ドラム曲率が夕イヤの摩耗に及ぼ す影響について, 接地面内の摩擦エネルギーを計 算することによって解析的に調べた。解析結果は, 過去に得られた結果 ${ }^{3)}$ と比較された。この結果フラ ットベルト上とドラム上での両者の摩擦エネルギ 一の関係が明らかになり, 同一横力を発生させた 


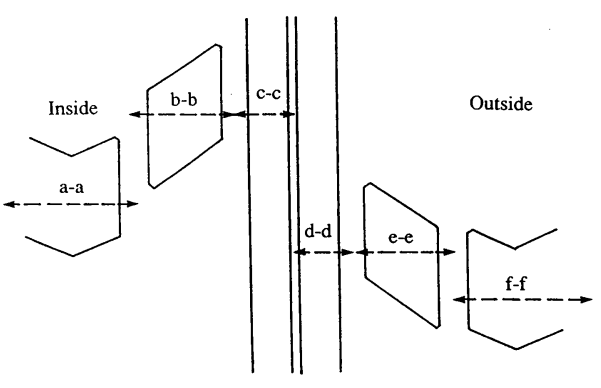

Fig. 1 Measurement points of tread wear

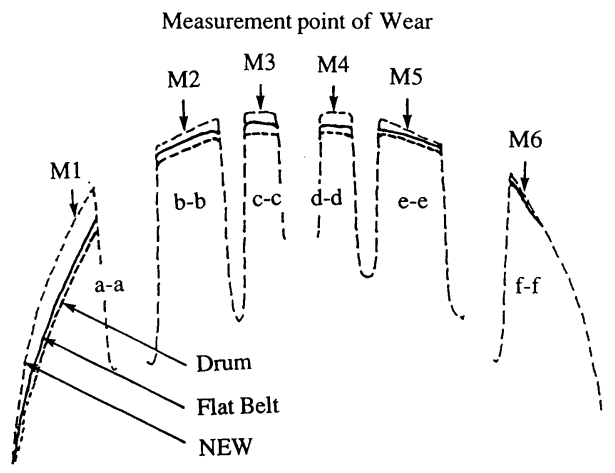

Fig. 2 Tread wear shape after traveling

とき，ドラム上の摩擦エネルギーが大きいことが わかった。 また，解析的に得られた結果は実験結 果とよく一致した。

\section{2. 試験 の 方 法3)}

\section{1 試 験 機}

タイヤの摩耗試験には，フラットベルト式タイ ヤ試験機およびドラム式タイヤ試験機(ドラム直径 $3.5 \mathrm{~m})$ を用いた。

\section{2 試験タイヤ}

試験には，サイズが205/60R $1589 \mathrm{H}$ の一般市 販タイヤを用いた。リムサイズは，15x6JJ を用い た.

\section{3 試験方法と試験条件}

摩耗試験の方法は, 一定の横力を発生させて走

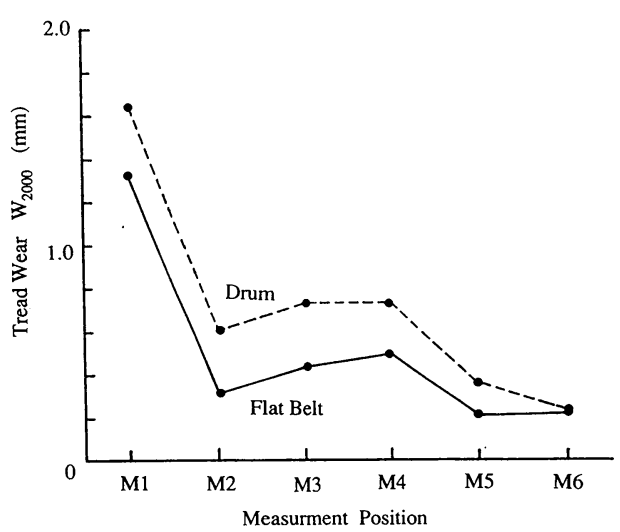

Fig. 3 Comparison of tread wear on the flat belt and drum surface

行させ，新品時と走行後の摩耗を各試験機で比較 した。摩耗試験時は，タイヤトレッド表面がチュ 一インガムのような粘着状態になるのを防ぐため にタルクを散布した。試験条件を以下に示す。 試験速度： $60 \mathrm{~km} / \mathrm{h}$

荷 重： $5.05 \mathrm{kN}$

空気圧 : $200 \mathrm{kPa}$

走行距離: $2000 \mathrm{~km}$

路面粗さ：\#240のサンドペーパー

横 力: $0.505 \mathrm{kN}$ (横向き加速度 $0.1 \mathrm{G}$ )

\section{4 摩 耗 量}

摩耗形状は，Fig. 1 に示すように，レーザー光 線を利用した摩耗形状測定装置で測定した。摩耗 形状の測定結果から，各トレッドブロック中心部 の新品時と走行後の減量を摩耗量とした。

\section{5 摩耗試験の結果}

Fig. 2 は，フラットベルトおよびドラムの摩耗 形状測定結果を示している。また，Fig. 3 は，フ ラットベルト上とドラム上での走行後の摩耗量を 比較したものである。

これらの図から，同一横力および同一荷重条件 で走行させたにもかかわらずドラム上のほうがフ ラットベルト上より摩耗量が大きいことがわかる。

\section{3. 摩擦エネルギーによる検証}

試験で得られた路面曲率の差異が夕イヤ摩耗に 及ぼす影響について，摩擦エネルギーを解析的に 求めて検証する. Fig. 4 に示すように，これまで 


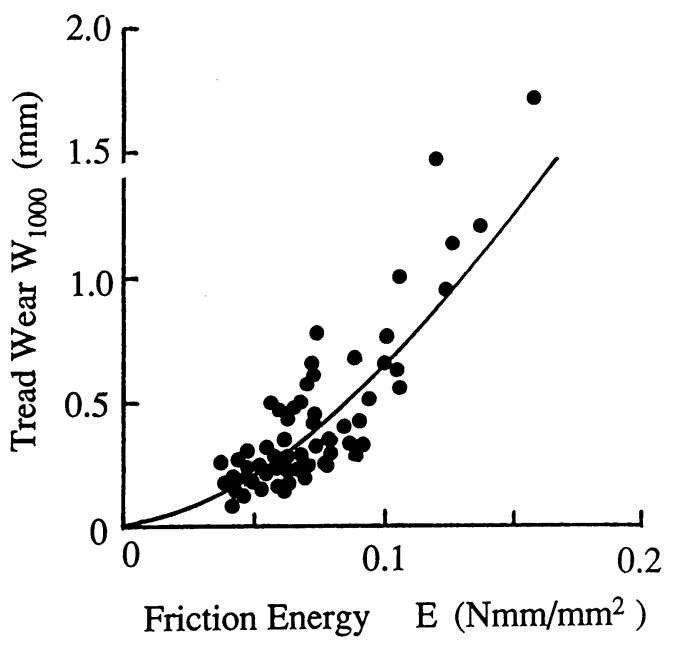

Fig. 4 Relationship between friction energy and tread wear

の研究によって, 走行中の夕イヤの接地面内の摩 擦エネルギーが大きいものは, 摩耗量も大きいこ とが知られている ${ }^{4)}$ 単位面積あたりの摩擦エネル ギーは，接地面内の任意の点の接地圧力とその点 の滑り量の積で与えられるものである.ここで，フ ラットベルト上とドラム上でのタイヤの接地面内 の単位面積あたりの摩擦エネルギーを計算し，両 者の摩擦エネルギ一の大きさを比較する。

\section{1 タイヤの接地圧力分布と接地荷重}

Fig. 5 に示すように，夕イヤの接地圧力分布は 放物線で，接地面は矩形であると仮定する ${ }^{5)}$.

フラット面の接地圧力分布を $p$, ドラム面の接地 圧力分布 $p^{\prime}$ とする接地圧力分布は, 次式で表さ れる。

$$
\begin{aligned}
& \text { ・ラットベルト上 } \\
& p=4 p_{m} \frac{x}{l}\left(1-\frac{x}{l}\right) \\
& \text { ドラム面上 } \\
& p^{\prime}=4 p_{m}^{\prime} \frac{x}{l^{\prime}}\left(1-\frac{x}{i}\right)
\end{aligned}
$$

ここで， $p_{m}$ は接地圧力の最大值を示し，lは夕イヤ の接地長さである。また，(') はドラム上での記 号を意味する。

次に, 重直荷重 $F_{Z}$ は接地圧力分布を接地面全体 で積分することによって次式のようにかける.

・フラット面上

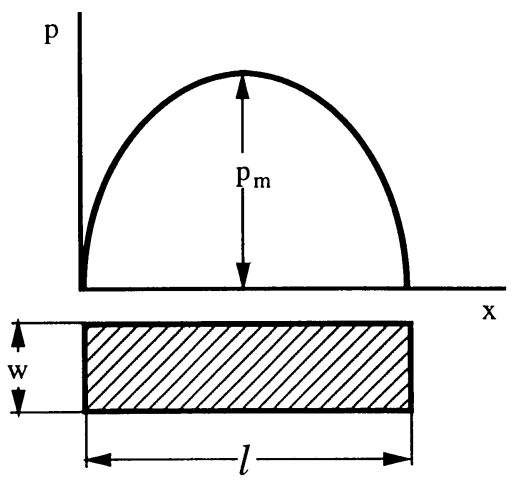

Fig. 5 Contact pressure distribution of tire

$$
F_{z}=\frac{2}{3} w l p_{m}
$$

・ドラム面上

$$
F_{z}^{\prime}=\frac{2}{3} w l^{\prime} p_{m}^{\prime}
$$

ここで，wは接地幅で，路面曲率に対してほぼ一 定であると仮定した。

一般に接地長さは，Fig. 6 に示すように，路面曲 率に影響される。ドラム径が小さくなると，同一 の荷重で接地長さが短くなる。いま，フラットべ ルト上とドラム上での接地長さの比を $A$ とすると 両者の関係は次式で表される.

$$
l^{\prime}=A l
$$

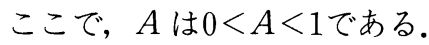

\section{2 タイヤに発生する横力}

タイヤに小さなスリップ角 $\alpha$ がつけられると Fig. 7 に示すように，接地面内に粘着域と滑り域が生じ る5). 粘着域と滑り域の境界である滑り出す点を $x_{S}$ とする. 任意の点の単位面積あたりの横力は，次 式で与えられる。

$$
C_{Y} x_{S} \tan \alpha
$$

ここで， $C_{Y}$ はトレッドゴムの単位面積あたりのせ ん断ばね定数である。単位面積あたりの横方向の 滑り摩擦力は次式で与えられる。

$$
\mu p
$$




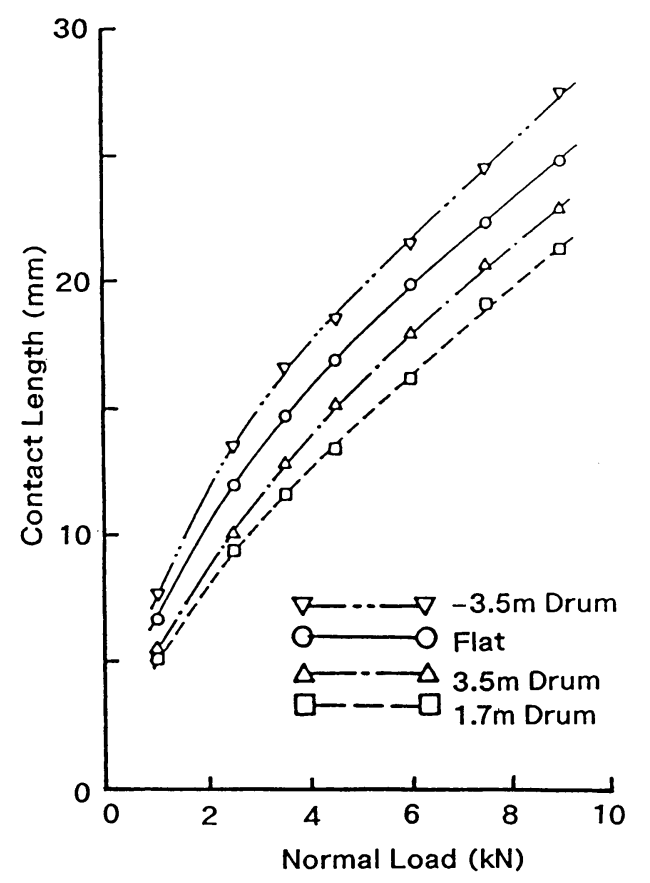

Fig. 6 Influence of drum curvature on contact length

出す点が次式のように求められる.

・フラットベルト上

$x_{s}=l-\frac{C_{Y} l^{2} \tan \alpha}{4 \mu p_{m}}$

ドラム面上

$x_{s}^{\prime}=l^{\prime}-\frac{C_{Y} l^{\prime 2} \tan \alpha^{\prime}}{4 \mu p_{m}^{\prime}}$

スリップ角がつけられたタイヤが発生する横力 $F$ $Y$ は，単位面積あたりの横力を接地面全体にわたっ て積分することによって与えられる。

・フラットベルト上

$$
\begin{aligned}
F \gamma & =w\left(\int_{0}^{x_{s}} C_{Y} x \tan \alpha d x+\int_{x_{s}}^{1} \mu p d x\right) \\
& =\left(\frac{1}{2} C_{Y} \tan \alpha x_{s}^{2}+\frac{2 \mu p_{m}}{3 l^{2}}\left(l-x_{s}\right)^{2}\left(l+2 x_{s}\right)\right) w
\end{aligned}
$$

ドラム面上

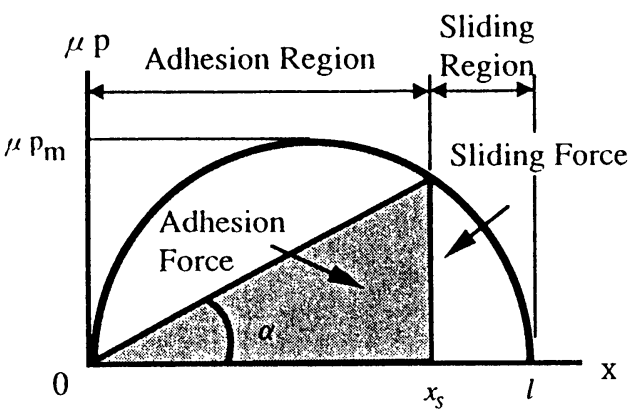

Fig. 7 Adhesion region and sliding region in contact patch

$$
\begin{aligned}
F_{Y}^{\prime} & =w\left(\int_{0}^{x_{S}^{\prime}} C_{Y} x \tan \alpha^{\prime} d x+\int_{x_{s}^{\prime}}^{l^{\prime}} \mu p^{\prime} d x\right) \\
& =w\left(\frac{1}{2} C_{Y} \tan \alpha^{\prime} x_{s}^{\prime 2}+\frac{2 \mu p_{m}^{\prime}}{3 l^{\prime 2}}\left(l^{\prime}-x_{s}^{\prime}\right)^{2}\left(l^{\prime}+2 x_{s}^{\prime}\right)\right)
\end{aligned}
$$

一般にタイヤのコーナリングスティフネス $K$ は， Fig. 8 に示すように，路面曲率に影響される。コ 一ナリングスティフネスとは, 微小スリップ角の とき, 単位スリップ角あたりに発生する横力のこ とで重要な特性である。コーナリングスティフネ スは，式(10)および(11)をスリップ角 $\alpha$ で微分し て $\alpha=0$ と置くことによって次式のように表せる.

・フラットベルト上

$$
K=\frac{1}{2} C_{Y} w l^{2}
$$

・ドラム面上

$$
K^{\prime}=\frac{1}{2} C_{Y} w l^{\prime 2}
$$

\section{3 フラットベルト上とドラム上でのタイヤ特 性の関係}

フラットベルト上とドラム上で, 垂直荷重およ び発生する横力が $F_{\mathrm{Z}}=F^{\prime}{ }_{\mathrm{Z}}, F_{\mathrm{Y}}=F^{\prime}{ }_{\mathrm{Y}}$ であるとした ときの, 両路面での夕イヤ特性の関係を求める.

(1) コーナリングスティフネス

コーナリングスティフネスの両路面の関係は, 式 (5)，式(12)および式(13)から，次式の関係が導 かれる。

$$
K^{\prime}=A^{2} K
$$

\section{（2）最大接地圧力}

最大接地圧力の両路面の関係は, 同様に式 (3), 式(4)および式(5)から次式で表せる. 


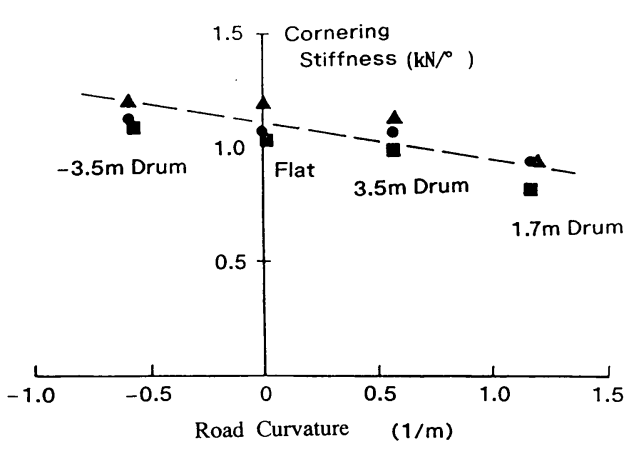

Fig. 8 Influence of drum curvature on cornering stiffness

$$
p_{m}^{\prime}=\frac{1}{A} p_{m}
$$

\section{(3) 滑り出す点}

フラットベルト上でのすべり出す点の式 $(8)$ お よび横力の式 (10)から, $C_{Y} \tan \alpha$ を消去すると次 式を得る.

$4 \mu p_{\mathrm{m}}\left(l^{3}-x_{\mathrm{s}}^{3}\right)=6 l^{2} F_{Y}$

この式を変形すると次式を得る。

$$
l^{3}-x_{s}^{3}=\frac{3}{2} \frac{l^{2} F_{Y}}{\mu p_{m}}
$$

よって滑り出す点は次式のようにかける.

$$
x_{S}^{3}=l^{3}-\frac{3}{2} \frac{l^{2} F_{Y}}{\mu p_{m}}
$$

同様に，ドラム上では，次式で表せる.

$$
x_{s}^{\prime 3}=l^{\prime 3}-\frac{3}{2} \frac{l^{\prime 2} F_{Y}^{\prime}}{\mu p_{m}^{\prime}}
$$

式(5)を式(17)に代入して整理すると次式が得ら れる。

$$
x_{s}^{\prime 3}=A^{3}\left(l^{3}-\frac{3}{2} \frac{l^{2} F_{Y}}{2 \mu p_{m}}\right)
$$

よって，上式と式(17)を比較すると，両路面での 滑り出す点の関係が次式のように与えられる.

$$
x^{\prime}{ }_{S}=A x_{S}
$$

（4）横力が等しくなるスリップ角

フラットベルトにおいて, 滑り出す点の式 ( 8) と横力の式 (10) から, $\mu \mathrm{p}_{\mathrm{m}}$ を消去すると次式を得 る.

$$
C_{Y} \tan \alpha=\frac{6 F_{Y}}{l^{2}+l x_{s}+x_{s}^{2}}
$$

上式を変形すると次式を得る。

$$
\frac{1}{2} C_{Y} x_{S}^{2} \tan \alpha=\frac{3 F_{Y} x_{S}^{2}}{l^{2}+l x_{S}+x_{S}^{2}}
$$

同様に, ドラムにおいて滑り出す点の式 $(9)$ と横 力の式(11) とから, 同様に次式を得る.

$$
\frac{1}{2} C_{Y} x_{S}^{\prime 2} \tan \alpha^{\prime}=\frac{3 F_{Y}^{\prime} x_{S}^{2}}{l^{\prime 2}+l^{\prime} x_{S}^{\prime}+x_{S}^{\prime 2}}
$$

スリップ角の両路両間での関係は，横力が等しい とし, 式 (5), 式(19)および式(20)から次式のよ うに表せる。

$$
\frac{1}{2} C_{Y} x_{s}^{\prime 2} \tan \alpha^{\prime}=\frac{1}{2} C_{Y} x_{s}^{2} \tan \alpha
$$

よって, 両路面で横力が等しいとするときのスリ ップ角の関係は,

$$
\tan \alpha^{\prime}=\frac{x_{s}^{2}}{x_{s}^{\prime 2}} \tan \alpha=\frac{1}{A^{2}} \tan \alpha
$$

と得られる。

以上の結果から，垂直荷重㧍よび横力が等しい ときのフラットベルト上とドラム上でのタイヤ特 性が，接地長さの比 $A$ で関係づけられることが示 された。

\section{4 摩擦エネルギー}

タイヤの摩耗は, 主に接地面内の滑りによって 生じると考之られる。一般に，摩擦エネルギーが 大きいものほど摩耗が大きいといわれている。そ こで，フラットベルト上とドラム上で夕イヤの接 地面内の摩擦エネルギーを求め, 路面の曲率によ る摩耗への影響を調べる。摩擦エネルギーは, 滑 り距離と発生するせん断力あるいは摩擦力の積で 与えられる。以下では，単位面積あたりの摩擦力 と滑り距離の積として単位面積あたりの摩擦工ネ ルギーを考える。

(1)横力が等しい場合の両路面の摩擦エネルギー

Fig. 9 は, 夕イヤの接地面内の単位面積あたり の摩擦力と滑り距離を表している. 図を参照して, 接地面内の滑り出す点におけるトレッドゴムの変

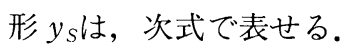

$$
y_{S}=x_{S} \tan \alpha
$$

滑り域 $x_{\mathrm{S}}<x<1$ において，トレッドゴムの変形は 次式となる。

$$
y=x_{S} \tan \alpha-r
$$

ここで，rはトレッドゴムの滑り距離である．横力 の釣り合いから，次式が与えられる。 


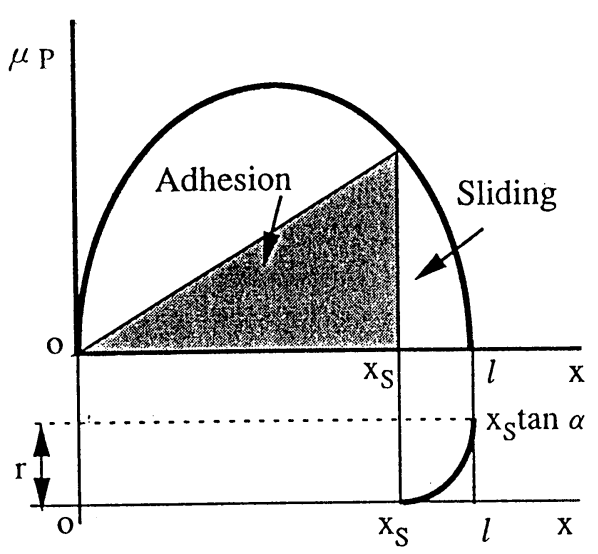

Fig. 9 Sliding distance in contact area

$$
X_{S} \tan \alpha-\gamma=\frac{\mu}{C_{Y}} p
$$

したがって，滑り距離が次式のように求められ

$$
\mathrm{r}=x_{s} \tan \alpha=\frac{\mu}{C_{Y}} p
$$

よって，フラットベルト上での単位面積あたりの 摩擦エネルギーは，次式のように表せる。

$$
\begin{aligned}
E & =\int_{x_{s}}^{l} \frac{d r}{d x} \mu p d x \\
& =\frac{16 \mu^{2} p_{m}^{2}}{C_{Y}} \int_{X s}^{1}\left(\frac{2 x}{l^{2}}-\frac{1}{l}\right)\left(\frac{x}{l}-\frac{x^{2}}{l^{2}}\right) d x \\
& =\frac{8 \mu^{2} p_{m}^{2}}{C_{Y}} \frac{x_{s}^{2}}{l^{2}}\left(1-\frac{x_{s}}{l}\right)^{2}
\end{aligned}
$$

ただし，式(23)から

$$
\frac{d r}{d x}=-4 \frac{\mu}{C_{Y}} p_{m}\left(\frac{1}{l}-\frac{2 x}{l^{2}}\right)
$$

である。

同様に，ドラム上での単位面積あたりの摩擦エネ ルギーは次式で与えられる。

$$
\begin{aligned}
E^{\prime} & =\frac{8 \mu^{2} p_{m}^{\prime 2}}{C_{Y}} \frac{x_{s}^{\prime 2}}{l^{\prime}}\left(1-\frac{x_{s}^{\prime}}{l^{\prime}}\right)^{2} \\
& =\frac{18 \mu^{2} p_{m}^{2}}{A^{2} C_{Y}} \frac{x_{s}^{2}}{l^{2}}\left(1-\frac{x_{s}}{l}\right)^{2}
\end{aligned}
$$

式(24)と式(26)を比較することによって, 両路面 の単位面積あたりの摩擦エネルギーの関係が次式 のように求められる.

$$
E^{\prime}=\frac{1}{A^{2}} E
$$

式(27)の関係から，同じ横力が発生するとき，ド ラム上での単位面積あたりの摩擦エネルギーはフ ラットベルト上よりかなり大きいことがわかる。し たがって，ドラム上のほうがフラットベルト上よ り摩擦が大きいことが表された。

(2) 両路面の摩擦エネルギーを等しくするための スリップ角

つぎに，両路面の摩擦エネルギーを等しくする ための両路面のスリップ角を求める。つまり，フ ラットベルト上とドラム上で摩耗量を等しくする ための互いのスリップ角の関係を導く.

単位面積あたりの摩擦エネルギーが互いに等し いと置くと,

$$
E=E^{\prime}
$$

となる，上式から，次式が導かれる.

$$
p_{m} \frac{x_{s}}{l}\left(1-\frac{x_{s}}{l}\right)=p_{m}^{\prime} \frac{x_{s}^{\prime}}{l^{\prime}}\left(1-\frac{x_{s}^{\prime}}{l^{\prime}}\right)
$$

式(28)に式(15)を代入して滑り出す点について整 理すると

$$
x_{S}{ }^{\prime 2}-A l x_{S}^{\prime}-A^{3} x_{S}^{2}+A^{3} l x_{S}=0
$$

をえる。この式から摩擦エネルギーが等しい場合 の両路面における滑り出す点の関係が求められる. 更に，式(28)に（5)，（8)，（9）および式(15)を 代大して整理すると次式が求められる.

$$
\tan \alpha^{\prime}=\frac{x_{s}}{x_{s}^{\prime}} \tan \alpha=\frac{1}{A} \tan \alpha
$$

この式から，フラットベルトと同じ摩擦エネルギ 一となるスリップ角が与えられ，この関係を用い ることによって，ドラム上とフラットベルト上で 同一の摩耗量がえられるものと考之られる.

\section{4 解析結果と実験結果の比較}

ここでは，解析による摩擦エネルギーの大きさ と摩耗試験による摩耗の大きさを比較し，フラッ トベルト上とドラム上での摩耗の差異を検証する。

フラットベルトにおけるタイヤの接地長さは， $l=$ $16 \mathrm{~cm}$ で，同一荷重下におけるドラム上での接地長

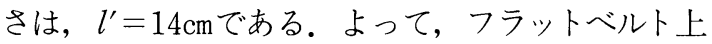
とドラム上の接地長さの差異は， $A=0.875$ となり 12.5\%である. したがって，式(27)から，フラット ベルト上とドラム上での摩擦エネルギーの差異は, 約 $30 \%$ となり，ドラムのほうが摩擦エネルギーが 大きい.この結果と Fig. 2 および Fig. 3 に示した タイヤの摩耗試験の結果を比較すると，フラット 
ベルト上よりドラム上のほうが約 $30 \%$ 摩耗量が大 きいことから，解析が有効であると確認できる.

したがって，ドラム上でフラットベルトと摩耗 量を等しくするときは，式(30)のスリップ角を用 いて試験すればよいと考えられる.

\section{4. あ と がき}

本研究では，フラットベルト上とドラム上の摩 耗量の差異について, 解析的に摩擦エネルギーを 求めることによって検証した。その結果, 発生す る横力が両路面で同じであっても, ドラム上の摩 耗がフラットベルト上より大きくなることが明ら かになった．したがって，ドラム上での試験は，フ ラットベルト上での試験より過酷度が大きいこと に注意が必要である。この結果は, 他のドラム状 の材料試験機, 例えば，ランボーン試験機などに も適用でき，ドラム面が実際の使用状態と異なる 曲率の場合は, 注意が必要であることを示唆して いる，更に，本解析手法を適用すれば，室内材料 試験が，実際に使用した摩耗結果と類似させるこ とができるものと考えられる，室内での材料評価
が実際の製品使用評価と異なることがときどき指 摘されるなか, 本研究が, 摩耗評価や材料開発に 役立てば幸いである。

\section{参 考 文 献}

1) Yamazaki, S., Fujikawa, T., Hasegawa, A. and Ogasawara, S., Indoor Test Procedures for Evaluation of Tire Treadwear and Influence of Suspension Alignment, Tire Science and Technology. TSTCA, Vol.17, No.4, October-December, 1989, pp.236-273.

2) Stalnaker, D., Turner, J., Parekh, D., Whittle, B., The Tire Society 14th Annual Meeting and Conference(1995)

3 ) Yamazaki, S., Masuda, M., Tozawa, Y. and Fujikawa, T., Effect of Road Surface Curvature and Road Roughness on Tire Treadwear, The Japan Society of Mechanical Engineers, The 3rd Transportation and Logistics Conference, 1994, pp.258261.

4) 山崎俊一, 夕イヤの摩耗評価方法々摩耗特性, 自動 車研究, Vol.3, No.4, 1991, 8-18.

5 ) Fiala E., Seitenkräfte am rollenden Luftreufen, V. D.I., Bd.96, Nr.29, 11, Okt., 1954.

$\cdot \operatorname{IRC}=ュ ー ス \cdot$

\section{IRC 98 PARIS 国際ゴム技術会議の開催について}

IRC 98 PARIS は, Association Francaise des lngenieurs et Cadres du Cautchouc et des Plastiques (AFICEP), Societe de Chimie Industrielle (S.C.I)の主催によって1998年 5 月12日(火)〜14 日(木)の 3 日間，CNIT PARIS LA DEFENSEにおいて開催いたします。

発表申込 1997年 6 月 1 日

申 込先 Societe de Chimie Industrielle IR 98 28, rue Saint-Dominique, F 75007 Paris

Tel.(0)1-53-59-02-10 Fax.(0)1-45-55-40-33

なお，2nd Announcement が事務局あて届いておりますので，御希望の方は下記あてお申し出下さ い.

社団法人 日本ゴム協会 国際会議係

東京都港区元赤坂1-5-26

電話03-3401-2957 FAX. 03-3401-4143 